\title{
Socio-Economic Effects of Globalization on Working Women in Sargodha City Pakistan
}

\author{
Nehdia Mahmood \\ Dr.Ghulam Yasin \\ Umair Ahmed \\ Dr. Yasir Nawaz \\ Asad Umair \\ Department of Sociology, University of Sargodha
}

\section{Doi:10.5901/mjss.2014.v5n3p561}

\begin{abstract}
Globalization is an emerging phenomenon for the last few decades. It has been effected many countries around the world and people living in them. Globalization has significant impact on multiple spheres of life. The present study concentrated to analyze the socio-economic effects of globalization on the working women in Pakistan. The major objectives of the study were to find out the impacts of globalization on women's socio-economic position and their participation in different economic activities. Population of the study was the working women of Sargodha city in Pakistan. In order to conduct the research, samples of 154 working women who were engaged in different fields selected through multi stage sampling. Nature of the study was quantitative, so questionnaire was used as a tool for data collection. Chi-square was used to analyze the collected data. Results revealed that globalization has significant impacts on women's socio-economic position. Majority of the respondents claimed that globalization has provided them access to multiple employment choices, enhanced their provisioning capacities, improved their professional skills and verbal abilities and most of all through this they gain control over resources which enhanced their decision making power in their life. Institutions or organizations should also play their role for enhancing women's position in society. This thesis contributes to the literature on the subject and will initiate debate on the issue so that further research can be deepened in this area.
\end{abstract}

Keywords: Globalization and women, Globalization

\section{Introduction}

The word 'globalization' is multi-dimensional. It has economic, social, cultural and political connotations. It is defined as a process of rapid economic integration among countries driven by the liberalization of trade, investment and capital flows, as well as technological change (Torres, 2001). Robertson (1992) described that globalization can be defined as the compression of the world, intensification of the whole world and in its thoughts and functions it makes the whole world a single unit. Globalization has minimized the differences among different countries and its nation. People of different countries interact with each other in multi spheres of their lives. The world has become a smaller place in present era, advancement in different spheres of life such as advances in transport system, computer networking, genetics and communication system led the entire world to become a single place. Internet has played a key role in this process, people can interact and communicate each other all around the world quiet easily due to this tool and everyone has easy access to the internet in the world. These advances has allowed the people to talk with their families and friends all around the world, travelling from one corner of the world to other now take few hours, computer networking and faxing has enabled world business to grow within few seconds. Images of one country are renowned all over the world such as images of Mickey mouse and McDonalds. People around the world not only exchange the material goods, they also exchange the ideas, thoughts and their emotions with each other (Galindo, 2009).

The last three decades have notified as the process of globalization, considering its all dimensions such as economic, political, cultural and social has been intensified. Since the early sixteen century national and regional economies around the world have been integrating and in twentieth century some indictors of globalization were very high. Recently globalization has gained amazing momentum in its denotation and depth (Beneria et. al, 2000). Elson \& 
Cagatay, (2000) explored that it is the reappearance of the neo-liberal economies around the world, the effects is globalized technological change, the development of multinational corporations and the enormous gathering of capital in the course of merger and acquisitions. Globalization's forces are the connotation of nationwide economy, hi-tech innovation, and process of production, distribution of resources, institutional changes and formulation of policies of the different countries of the world.

Globalization has the tremendous impacts on both of the gender (male and female) and also on their families. The most observed impact of globalization is increased participation of female in paid labor market more than males (Standing, 1999). Marchard \& Runyan, (2000) and Pyle \& Ward (2003) described that global processes change gender system, relations and roles and reinforce gender inequalities, but they are also embedded in a gendered reality and gendered ideologies. Therefore, globalization reinforces gender formations. The processes of globalization are fused with gender ideologies. The traditional gender roles and gender inequalities have not remained same as they were in past eras. In different third world countries men are moving to urban centers and cities in search of better paid work, due to their absence at house women have been come into labor, as well as in agriculture sphere to perform their tasks. In this situation women usually become household heads and primary wage earners. As women adopt the role of wage earner it boost up their abilities to perform work, they own money which they earn. This ownership of money gives them more authority in family decision-making; consequently it results in changing the gender roles (Pyle \& Ward, 2003). The earlier ethnographies of feminism declared that gender was generally empirically viewed by taken into account the impacts of globalization on the region and the life of woman. Though, feminist scholars have theoretically discussed current globalization; several studies of feminist concentrate on two aspects of globalization which are micro and macro (Freeman, 2001). Through the application of globalization for employment of women brings a whole range of variety in services, self independence but the glass ceiling still exist. Researchers related to different areas of study such as Sociology, Economics and Anthropology collected empirical data that demonstrates the price of globalization in developing countries upon the livings of women and the family members of their home. Feminists argue that gendering our analysis of globalization increases the understanding of what globalization is and how it works, how it affects people's lives, how he was influenced by the speeches and hierarchies between genders and how these hierarchies gender determine to turn global institutions and relationships? (Moghadam, 1999). With era of globalization, Women are too burdened by the need to engage in two kinds of roles one of these role is the role of bread winner (wage earner) and their traditional role. The role of a person that holds the charge and responsibilities of household, on the other side man feels that woman's role of wage earner is threat to his dominance at household level and also in several spheres of his life. It has destabilized the role of men as there are more choices and economic opportunities for women. These choices, opportunities, employments and advanced technologies not only bring prosperity, freedom and success for women even though this can grounds a disaster at household. Independence of women sometimes results in violent reactions of men. The processes of globalization changed gender systems and relationships (Momsen, 2004). Walby, (1997) described that femininity is not defined more just by motherhood and domesticity. On the one hand, women's participation in traditionally male fields alters the forms of masculinity and the role of men and also threatens men to take 'their' jobs. Response to this is that they attempt to re-establish the traditional patriarchy and its system that can consequence in a re-emergence of violence typically against women.

"In the world, women have about 1 percent of the total property of the entire world. Consequently, women have engaged in the globalization process in the course of getting access to market. As compare to the worker that work in production process women deliver services in addition to that workers, women's additional services are: sexual and domestic but they still get low wages "they are not under the hold of the massive financial and flows of export in a globalized economy" (Rai, 2002). Cheng (1999) argued that the increase in women participation in economic sector due to globalization resulted in narrowing the wage gap between men and women. Therefore women are able to live their lives independently. The variations that have been suddenly occurred by globalization, in particular it has improved access to economic opportunities and information among women. Women that are holding income may be lead towards the better positioning of woman at household level by having control over their income and it may also help them in changing their gendered specific role at home as due to the resources that woman own they can experience power in their household. In fact, women come to better control their income working in focused activities on export, even the impact on welfare and the Agency is more positive for women working in manufacturing and far from their male relatives for those working in agriculture. In factories, women feel that their situation has improved (Hewitt et al., 2001). Deo (2006) \& gray et al. (2006) stated that there is body of evidences that women can improve their ranks and lives due to the avenues opened by economic globalization.

National report in Pakistan (1995) explored that in Pakistani society the situation of Pakistani women is not 
homogenous because there is a huge flaw among different strata's of the society. There is noteworthy diversity in the condition of women social status, regions and the urban/rural gap due to socio-economic development. In Pakistani society there is also the impact of feudal, tribal, and industrialist social formations upon the lives of women. Women and the girls of Pakistan typically spend a long time in domestic work such as doing laundry, fetching water, making food and also the agricultural tasks. All the tasks that women of Pakistan perform are challenging and demands physically more strength and these tasks rob also daughters of the chance to study. Women are deficient in possession of productive resources. Despite the legal rights of women to be the owner of their family, there are practically hard to find a single woman who has access and power to use these resources. In 1995 a survey in Punjab containing 1,000 rural households micro level, revealed that only 36 women owned land in their own name, while only 9 of them had control over it. Bari (1997) described that formal financial institutions do not meet the credit needs of women because of the assumption of the role of women in reproduction. Commercial banks pay no attention to the clients of women because of their preconceived opinions on the creditworthiness of the woman because of their dependence on the men of physical collateral, transaction cost high low and the difficulties in obtaining information on the reliability of the borrower. In the labor market the nature and the area of the productivity of women is fundamentally determined by the factors of economy and social cultural. Women are not equal to men in labor market. Women's work force is considered low level because of the preset notion employers in the female lead role in the foyer. Because discrimination against women's work, women are usually given low paid and low status work, work that cannot provide them opportunity for boosting up their earnings and life styles. Women are determined to perform the work of secondary sector in the labor market. Pakistani Women, as elsewhere in the third world, due to the competition face growing insecurity. In addition, there is no guarantee of access to opportunities to increase unless measures are taken to increase their socio-economic empowerment.

\section{Purpose of the Study}

Globalization has affected the socio-economic situation of women and had significant impacts on the participation of women in economic activities. Especially in Pakistani society there is no admittance towards social services, decision making process and equal opportunity to employment in the labor market. Previous studies on globalization and its impact has shown that women do not endow with satisfactory literature to properly analyze the extant of backwardness and the causes of gender bias in Pakistani society. The present study aims to provide an ever view of the effects of globalization.

Important questions which are addressed in the course of study include:

i. To examine the female participation in economic activities.

ii. To see the impact of globalization on women socio-economic position.

iii. To investigate inequality among male and female in economic sphere due to globalization.

iv. To investigate occupational segregation among male and female due to globalization.

\section{Methodology}

According to the requirement of the study quantitative method was used for conducting a research. Population of the study was all the working women of the Sargodha city. The study was to investigate that to what extant globalization has affected the socio-economic position of women in Sargodha city as it has tremendous impacts in developed cities. In order to conduct the study, a sample of 154 working women was selected through multistage sampling. At first stage of sampling, researcher drew the clusters of different formal sectors such as education institutes, banking and NGO's sectors in Sargodha city. While in second stage, the 10\% population was selected from each cluster from the working fields and in third stage the researcher approached the respondents conveniently. The quantitative method was used for conducting a research. In the present study, questionnaire was used as a tool of data collection. Questionnaire contained 51 items to take the opinion of working women about the effects of globalization on women's socio-economic position. These items covered all the variables included in study. Questionnaires were distributed personally to the working women who were included in the sample of the study. In this study the data was analyzed by using "SPSS" program. Hypotheses were constructed in the light of previously conducted researches and the hypotheses were tested on the basis of empirical evidence taken from data. Chi-square test was applied to match up observed data. In order to evaluate the significance associated between attribute, the calculated value of chi square were compared with corresponding table. 0.05 level of significance. The results are considered significant if the calculated value of chi square is greater than tabulated value otherwise regarded as non significant value. 
Table 1: Percentage distribution of respondents regarding the access to multiple employment choices due to emergence of global market.

\begin{tabular}{|c|c|c|}
\hline Responses & Frequency & Percent \\
\hline To Greater Extant & 71 & 46.1 \\
\hline To Some Extant & 61 & 39.6 \\
\hline Not At All & 22 & 14.3 \\
\hline Total & 154 & 100.0 \\
\hline
\end{tabular}

In the above mentioned table it is shown that $40.9 \%$ of the respondents said that, to some extent, they have easy access towards multiple employment choices due to emergence of global market and $39 \%$ responded that to greater extant they have this access. While only $20.1 \%$ of the respondents denied that they have any easy access towards multiple employment choices due to the emergence of the global market. Cheng (1999) also confirmed present data in his study that women's increased access to jobs under globalization tends to narrow the gender gap in earnings, thereby better positioning themselves to live independent lives.

Table 2: Percentage distribution of respondents regarding the effect of globalization on the batter chances in improvement of professional skill

\begin{tabular}{|c|c|c|}
\hline Responses & Frequency & Percent \\
\hline To Greater Extant & 73 & 47.4 \\
\hline To Some Extant & 59 & 38.3 \\
\hline Not At All & 22 & 14.3 \\
\hline Total & 154 & 100.0 \\
\hline
\end{tabular}

In the above mentioned table it is revealed that $46.8 \%$ of the respondents gave response that to greater extant due to the globalization they are in a position to get better chance to improve their professional skills. While $45.5 \%$ of the respondents said that, to some extent, they get this chance. Only $7.8 \%$ respondents denied that globalization is providing them with the chance to improve their professional skills. Gray et. al, (2006) also confirmed present data in his study that there is a body of empirical evidence supporting the assertion that economic globalization opens avenues in which women can enhance their status.

Table 3: Percentage distributions of respondents regarding the effect of economic advancement on the social protection

\begin{tabular}{|c|c|c|}
\hline Responses & Frequency & Percent \\
\hline To Greater Extant & 69 & 44.8 \\
\hline To Some Extant & 51 & 33.1 \\
\hline Not At All & 34 & 22.1 \\
\hline Total & 154 & 100.0 \\
\hline
\end{tabular}

Data revealed that $44.8 \%$ respondents were in favor that, to some extent, the economic advancement has effect on the experience of social protection. While $31.8 \%$ respondents gave response that, to greater extant, this economic advancement has any effect on the social protection and only $23.4 \%$ of the respondents denied that economic advancement has any effect on the social protection. Levine (2006) also confirmed present data in his study that economic growth should help facilitate higher government expenditures on health, education and other services that would directly benefit women.

Table 4: Percentage distribution of respondents regarding the effects of multinational corporations on batter employment opportunities.

\begin{tabular}{|c|c|c|}
\hline Responses & Frequency & Percent \\
\hline To Greater Extant & 82 & 53.2 \\
\hline To Some Extant & 48 & 31.2 \\
\hline Not At All & 24 & 15.6 \\
\hline Total & 154 & 100.0 \\
\hline
\end{tabular}


The above mentioned data revealed that $71.4 \%$ of the respondents were in favor that the multinational corporations have any effect on the employment opportunities and only $28.6 \%$ respondents were of the view that multinational corporations has no effect on the employment opportunities. Joekes (1995) also confirmed present data in his study that the importance of MNC employment is not only restricted to the manufacturing sector. Service sector MNCs are seen as representing important new sources of relatively well-paid and long-term employment opportunities for women.

\section{Testing of Hypothesis}

\subsection{Hypothesis 1: Increase in Financial resources through the globalization increase the social protection of the people}

The cross tabulation between the social protection and increase of financial resources through globalization

\begin{tabular}{|c|c|c|c|c|}
\hline \multirow{2}{*}{$\begin{array}{c}\text { Access over financial resources is } \\
\text { increasing as compare to previous years. }\end{array}$} & \multicolumn{3}{|c|}{$\begin{array}{c}\text { Experience social protection through economic } \\
\text { advancement. }\end{array}$} & \multirow{2}{*}{ Total } \\
\cline { 2 - 4 } & To Greater Extant & To Some Extant & Not At All & \\
\hline To Greater Extant & 51 & 13 & 7 & 71 \\
\hline To Some Extant & 12 & 31 & 8 & 51 \\
\hline Not At All & 6 & 7 & 19 & 32 \\
\hline Total & 69 & 51 & 34 & 154 \\
\hline
\end{tabular}

Chi square value $=65.193 ; \mathrm{Df}=4 ; \mathrm{P}$ value $=0.000^{\star *} ;$ Level of significance $=0.05$

\subsubsection{Discussion:}

Above table shows the results from cross tabulation of the variables social protection through economic advancement and the increase of financial resources through globalization, from the results it can be concluded that the relationship between the two variables is highly significant and the alternative hypothesis is accepted because the $p$-value is $.000^{\star *}$. This table signifies that there is an association between the two variables (increase in financial resources and social protection). Thus the hypothesis is accepted and the null hypothesis is rejected. Levine (2006) also confirmed present data in his study that economic growth should help facilitate higher government expenditures on health, education and other services that would directly benefit women.

4.2 Hypothesis 2: Increase the multinational corporations due to globalization in the society is major cause of employment choices

The cross tabulation between multiple employment choices and influence of multinational corporations on employment opportunities

\begin{tabular}{|c|c|c|c|c|}
\hline \multirow{2}{*}{$\begin{array}{c}\text { Multinational corporations hold influence } \\
\text { on my employment opportunities. }\end{array}$} & \multicolumn{2}{|c|}{$\begin{array}{c}\text { Easily get access to multiple employment choices due to } \\
\text { emergence of global market. }\end{array}$} & \multirow{2}{*}{ Total } \\
\cline { 2 - 4 } & To Greater Extant & To Some Extant & Not At All & \\
\hline To Greater Extant & 50 & 24 & 8 & 82 \\
\hline To Some Extant & 14 & 28 & 6 & 48 \\
\hline Not At All & 7 & 9 & 8 & 24 \\
\hline Total & 71 & 61 & 22 & 154 \\
\hline
\end{tabular}

Chi square value $=22.283 ; \mathrm{Df}=4 ; \mathrm{P}$ value $=0.000^{\star \star} ;$ Level of significance $=0.05$

\subsubsection{Discussion:}

Above table shows the results from cross tabulation of the variables multiple employment choices and influence of multinational corporations on employment opportunities, from the results it can be concluded that the relationship between above variables is highly significant because the $p$-value is $0.000^{\star *}$. The table depicts that due to globalization, the multinational corporation providing the multiple job opportunities for the women by whom they can get any job according to their choices. Os there is an association between the multinational corporations and employment choices. Thus the hypothesis is accepted and the null hypothesis is rejected. Joekes (1995) also confirmed present data in his 
study that the importance of multinational corporations employment is not only restricted to the manufacturing sector. Service sector multinational corporations are seen as representing important new sources of relatively well-paid and long-term employment opportunities for women.

\subsection{Hypothesis 3: There is an association between improve professional skills and improved living standard (with respect to globalization)}

Cross tabulation between better chances to improve professional skills and improved living standard.

\begin{tabular}{|c|c|c|c|c|}
\hline \multirow{2}{*}{ Living standard improves due to job. } & \multicolumn{2}{|c|}{ Better chances to improve professional skills due to globalization. } & \multirow{2}{*}{ Total } \\
\cline { 2 - 4 } & To Greater Extant & To Some Extant & Not At All & \\
\hline To Greater Extant & 45 & 18 & 6 & 69 \\
\hline To Some Extant & 21 & 33 & 7 & 61 \\
\hline Not At All & 7 & 8 & 9 & 24 \\
\hline Total & 73 & 59 & 22 & 154 \\
\hline
\end{tabular}

Chi square value $=26.185 ; \mathrm{Df}=4 ; \mathrm{P}$ value $=0.000^{* *} ;$ Level of significance $=0.05$

\subsubsection{Discussion}

Above table depicts the results from cross tabulation of the variables improvement in professional skills and living standard, from the results it can be concluded that the relationship between these two variables is highly significant because the $p$-value is $0.000^{\star *}$. So it is concluded that the globalization has improved the professional skills of the women and through their professional skills, they are improving their living of standards. Gray et. al, (2006) also confirmed present data in his study that there is a body of empirical evidence supporting the assertion that economic globalization opens avenues in which women can enhance their status.

\section{Conclusion}

Globalization is a term which is used to describe the way that how human beings all around the world have came close to one another and how it has minimized the geographical constrains. Globalization holds significant impact on different strata's in Pakistani society. The present research was conducted to study the effects of globalization on women's socioeconomic position in Sargodha city. Globalization has influenced women's life in different aspects of their socioeconomic position i.e increase in financial resources, multiple job opportunities, better chances to improve professional skills, enhancement in decision making, control on financial resources and social protection of women. The research concluded that the majority of the respondents claimed that they have more access to other resources such as health, economic and educational facilities due to advance technology and increase in employment opportunities. Levine (2006) also reported that the multinational corporations have significant impact on women employment choices. Joekes (1995) also confirmed present data in his study that the multinational corporations are seen as representing important new sources of comparatively well-paid and long-term employment opportunities for women. Globalization has provided better chances to improve professional skills and information. Technological means were the major factors that lead to better socio-economic position of women. In the present research, Majority of the respondents has easy access to multiple employment choices due to emergence of global market and multinational corporations and they experienced social protection through economic advancement. Globalization has also given autonomy to working women to make decisions about their life after having access on resources. Study revealed that globalization helped women to increase their socioeconomic position than last few years back. Globalization has brought improvement in women's socio-economic position. Due to globalization, more women have more opportunities for income generating employment and getting autonomy over their own earning and moving towards the independence from their traditional role such as marriage, childrearing and domestic unpaid work. Women are also becoming the brea

dwinners in most households because of the lack of male responsibility in the household. Young daughters are financially supporting their parents and fellow siblings, while mothers (married or single) are seeking informal work to provide for their children. Globalization has changed the intra-household responsibilities for males and females, where females are given more responsibility over the survival of the family. 


\section{Suggestions}

1. Institutions or organizations should also play their role for enhancing women's position in society.

2. Occupational segregation on gender basis should be abolished. So, women can also perform their role in managerial posts.

3. Electronic and print media should play their role in acknowledging the role that working women play for their families and for the country as a whole as their income increase GDP of the country.

\section{References}

Bari, F. (1997). "Women and Access to Credit: A Case Study of Pakistan," Islamabad.

Beneria, L.,Floro, M., Gowan, C. and MacDonald, M. (eds), (2000). Special Issues on Globalization, Feminist Economics.) Special Issue on globalization, Feminist Economics, vol.6, no.3.

Cheng, L. (1999). Globalization and women's paid labor in Asia. International social science Journal 52(160): 217-228.

Deo, N. (2006). Is globalization our friend? Women's allies in the developing world. Current History 105(689): 105-111

Elson, D. (1992). "From survival strategies to transformation strategies: Women's needs and structural adjustments." Pp. $26-48$ in unequal Burden: economic crises, persistent poverty and women's work. Lourdes Beneria and Shelley Feldman, editors. Boulder, co:west view Press.

Freeman, C. (2001). High tech and high heels in the global economy Freeman, Carla. 2001 'is local: global as fermine: masculine? Rethinking the gender of globalization.'

Galindo, L. (2009). Globalization. Available at http://www.scribd.com/doc/13760209/ Globalization-Essay.

Gray, M., Kittilson, C. and Sandholtz, W. (2006). Women and globalization: a study of 180 countries, 1975-2000.

Greer, G. (2000). 'Recantation', in The Whole Woman (London) p4.

Hewtt, Paul C, Sajeda, A. and Binayak, S. (2001). "Assessing the Impact of Garment Work on Quality of Life Measures." In Growth of the Gament Industry in Bangladesh: Economic and Social Dimensions, ed. Binayak Sen. Dhaka: UPL Publications.

Jookes, P. (1995) trade-related employment for women in industry and services in developing Countries. Occasional paper, un fourth world conference on women. Geneva: united Nations research institute for social development.

Khan S. R. (1997). Structural Adjustment in Pakistan: Testing Hypotheses and Assessing Impact, Islamabad, P.204.

Levine, R. (2006). Educating girls, unlocking development. Current history 105 (689)L 127131.

Marchard, H, M. and Runyan S.A (2000). Gender and Global Restructuring. Millennium - Journal of International Studies Kantola 30 (2): 449.

Moghadam, M. (1993). Gender dynamics of restructuring in the semi-periphery. Wider Research for action series. New York: United Nations University.

Moghadam, M. (1999). Gender and globalization: female labor and women's mobilization. Joural of world systems research 5(2): 367388.

Momsen, H. (2004). Gender and development. New York: routledge.

Pakistan National Report, (1995). Country briefing paper: Women in Pakistan. Asian development bank programs department (west) and office of environment and social development.

Pyle, L Jean. And Ward, K. (2003). 'recasting our understanding of gender and Work during global restructuring.' International sociology 18 (3): 461-489.

Robertson, R. (1992). "The Globalization Paradigm: Thinking Globally." Pp. 207-24 in Religion and Social Order. Greenwhich: JAI Press.

Torres, R. (2001) Towards a socially sustainable world economy: An ana lysis of the social pillars of globalization, Geneva, International Labour Office.

Walby, S. (1997). Gender Transformations. New York: Routledge. 